\title{
Coordinate Changes in Myosin Heavy Chain Isoform Gene Expression Are Selectively Associated With Alterations in Dilated Cardiomyopathy Phenotype
}

\author{
W. T. Abraham, ${ }^{1}$ E. M. Gilbert, ${ }^{3}$ B. D. Lowes, ${ }^{1}$ W. A. Minobe, ${ }^{1}{ }^{\text {P. Larrabee }}{ }^{2}{ }^{2}$ R. L. Roden, $^{1}$ D. Dutcher, ${ }^{1}$ \\ J. Sederberg, ${ }^{1}$ J. A. Lindenfeld, ${ }^{1}$ E. E. Wolfel, ${ }^{1}$ S. F. Shakar, ${ }^{1}$ D. Ferguson, ${ }^{1}$ K. Volkman, ${ }^{2}$ \\ J. V. Linseman, ${ }^{1}$ R. A. Quaife, ${ }^{1}$ A. D. Robertson, ${ }^{1}$ and M. R. Bristow ${ }^{1}$ \\ ${ }^{1}$ Division of Cardiology, University of Colorado Health Sciences Center, Denver, Colorado, USA \\ ${ }^{2}$ Division of Cardiology, University of Utah Health Sciences Center, Salt Lake City, Utah, USA \\ ${ }^{3}$ Division of Cardiovascular Medicine, University of Kentucky College of Medicine, Lexington, \\ Kentucky, USA
}

Accepted September 14, 2002

\begin{abstract}
Background: The most common cause of chronic heart failure in the US is secondary or primary dilated cardiomyopathy (DCM). The DCM phenotype exhibits changes in the expression of genes that regulate contractile function and pathologic hypertrophy. However, it is unclear if any of these alterations in gene expression are disease producing or modifying.

Materials and Methods: One approach to providing evidence for cause-effect of a disease-influencing gene is to quantitatively compare changes in phenotype to changes in gene expression by employing serial measurements in a longitudinal experimental design. We investigated the quantitative relationships between changes in gene expression and phenotype n 47 patients with idiopathic DCM. In endomyocardial biopsies at baseline and 6 months later, we measured mRNA expression of genes regulating contractile function $(\beta$-adrenergic receptors, sarcoplasmic reticulum
\end{abstract}

$\mathrm{Ca}^{2+}$ ATPase, and $\alpha$ - and $\beta$-myosin heavy chain isoforms) or associated with pathologic hypertrophy $(\beta$-myosin heavy chain and atrial natriuretic peptide), plus $\beta$-adrenergic receptor protein expression. Left ventricular phenotype was assessed by radionuclide ejection fraction.

Results: Improvement in DCM phenotype was directly related to a coordinate increase in $\alpha$ - and a decrease in $\beta$ myosin heavy chain mRNA expression. In contrast, modification of phenotype was unrelated to changes in the expression of $\beta_{1^{-}}$or $\beta_{2}$-adrenergic receptor mRNA or protein, or to the mRNA expression of sarcoplasmic reticulum $\mathrm{Ca}^{2+}$ ATPase and atrial natriuretic peptide.

Conclusion: We conclude that in human DCM, phenotypic modification is selectively associated with myosin heavy chain isoform changes. These data support the hypothesis that myosin heavy chain isoform changes contribute to disease progression in human DCM.

\section{Introduction}

Disease phenotypes are ultimately the result of changes in gene expression. In the chronically failing hypertrophied human heart, selective changes in the expression of genes that could potentially modify phenotype have been reported (1-8), typically in explanted human hearts at the end stage of the disease process (1-6). Reported alterations in gene expression in this setting include changes in the mRNA or protein expression of components of $\beta$-adrenergic signal transduction $(2-4)$, calcium handling proteins $(1,5)$, and contractile proteins (6). However, in these studies it has been difficult to determine which alterations in gene expression are fundamentally related to contractile dysfunction as opposed to those which are epi-

Address correspondence and reprint requests to: Michael R. Bristow, Head, Division of Cardiology, University of Colorado Health Sciences Center, 4200 East 9th Avenue, Campus Box B139, Denver, CO 80262. Phone: (303) 315-3250; fax: (303) 315-3261; e-mail: Michael.Bristow@UCHSC.edu. phenomena associated with advanced disease. Another interpretative challenge in these studies has been the difficulty of distinguishing between adaptive versus maladaptive processes, because many of the described changes are products of compensatory mechanisms that can produce either benefit or harm.

Additionally, because end-stage failing hearts or the organ donor-procured controls used in these studies may be affected by a multitude of ancillary factors, it is important to ultimately investigate gene expression in the intact heart. In the intact heart, starting material can be obtained from less advanced myocardial failure and controls are not subjected to the profound homeostatic disruption of brain death (9). Also, studies in the intact heart may be conducted longitudinally employing serial measurements $(8,10-12)$, which theoretically allows for detection of gene expression changes more directly associated with phenotypic modification. Importantly, because gene regulation is combinatorial (13), a strong case can be made for investigating 
gene expression in intact tissues where the net effect of multiple regulatory influences can be assessed.

Using reverse transcription quantitative PCR (RT-QPCR), it is possible to measure the steadystate mRNA abundance of multiple genes in small amounts of starting material (14), such as endomyocardial biopsy $(1,7,8,12,15)$. Treatment of chronic heart failure subjects with $\beta$-adrenergic blocking agents is associated with improvement in systolic function and a reversal of remodeling in the majority of subjects with a dilated phenotype (16), within a time frame of 4 to 12 months (16-21) that is amenable to serial investigation. This contrasts with the time course of the natural history of dilated cardiomyopathies, which is that of slow (time course of years) progression in phenotype and clinical sequelae $(22,23)$. The current investigation is an analysis of the quantitative relationships between changes in phenotype and the expression of contractilityregulating or pathologic hypertrophy-associated genes in a subject population of idiopathic dilated cardiomyopathy (IDC) patients treated for 6 months with placebo or $\beta$-adrenergic blockade.

\section{Methods}

Clinical Protocol

This study was designed to investigate changes in gene expression associated with phenotypic modulation in IDC, irrespective of treatment. Fifty-three subjects with symptomatic IDC and left ventricular ejection fraction (LVEF) were randomized to 6 months treatment with placebo, metoprolol tartrate, or carvedilol. Details of this treatment protocol are published elsewhere (8). Forty-nine subjects completed this protocol, and the current report concerns the 47 individuals who had complete (baseline and after 6 months of treatment) mRNA $(n=45)$ or $\beta$ adrenergic receptor protein $(n=36)$ measurements.

\section{Right Ventricular Endomyocardial Biopsy and Right Heart Catheterization}

Right heart catheterization and endomyocardial biopsy with allocation of tissue for mRNA and $\beta$-receptor protein measurements were performed from the right internal jugular vein as previously described $(7,8)$.

\section{Messenger RNA Expression Measurements in Endomyocardial Biopsy Material}

Messenger RNA abundance for six different genes $\left(\beta_{1^{-}}\right.$and $\beta_{2}$-adrenergic receptors, $\alpha$ - and $\beta$-myosin heavy chain $[\mathrm{MyHC}$, atrial natriuretic peptide [ANP], and SR $\mathrm{Ca}^{2+}$ ATPase [SERCA-2a or SRCA]) was quantified in extracted total RNA, by RT-PCR using previously described methods $(7,8)$.

\section{$\beta$-Adrenergic Receptor Measurements in Endomyocardial Biopsy Material, Catecholamine Measurements}

Total $\beta$-receptor density and $\beta_{1^{-}}$and $\beta_{2}$-receptor subtypes were measured in biopsy material as previously described $(7,8)$. Norepinephrine and epinephrine were determined in plasma from coronary sinus blood by a previously described radioenzymatic method (11).

Left and Right Ventricular Ejection Fraction Measurements by Radionuclide Ventriculography

LVEF and right ventricular ejection fraction (RVEF) were measured by in vitro red blood cell labeling and imaging techniques as previously described $(18,20)$, and the results were expressed in EF units ([stroke volume/end diastolic volume] $\times 100$ ). For RVEF a first-pass technique was employed, and for LVEF an equilibrium technique was used.

\section{Statistical Analysis}

The 45 subjects who had baseline and end-of-study mRNA measurements were rank ordered according to change in LVEF into three groups without regard to treatment type. For the 45 subjects who had baseline and end-of-study mRNA measurements, 15 subjects with an LVEF change from -11 and +2 (average $-2.2 \pm 1.1$ [standard error of the mean; SEM]) EF units comprised the Declined/No Change function group, 15 subjects with an LVEF change from +5 and +17 (average 12.2 \pm 0.9 ) EF units comprised the Improved group, and 15 subjects with changes from +18 and +44 (average $25.5 \pm 1.8$ ) EF units comprised the Marked Improvement group. The 36 subjects who had baseline and end-of-study receptor protein measurements were also rank ordered by LVEF change. Eleven subjects comprised the Declined/No Change function group (average change $-3.5 \pm 1.2 \mathrm{EF}$ units, range -11 to $+1 \mathrm{EF}$ units), 13 subjects were in the Improved group (average change $8.5 \pm 1.1 \mathrm{EF}$ units, range 2-13 EF units), and 12 subjects were in the Marked Improvement group (average change 23.1 $\pm 1.6 \mathrm{EF}$ units, range 16-34 EF units). We chose to rank order ventricular function change by LVEF rather than RVEF because (1) gene expression changes on the right side of the septum are closely related to those that occur in both the LV and RV free walls (6), presumably because the septum is a wall shared by both chambers, (2) with radionuclide techniques LVEF is more accurately measured than is RVEF (24), (3) 14 of the 45 study subjects had normal ( $\geq 40$ EF units) RVEF values at baseline, and (4) as shown in Results, the ordered classification of LVEF changes also resulted in incrementally increasing RVEF changes.

Changes in receptor protein, mRNA, and other variables of interest among the three LV function change groups were analyzed by three methods. In the first method, in which the LV function change groups were treated as ordinal variables, the relationships between various interval-level outcome variables and the ordinal-level change in LVEF were assessed with an ordinal trend test. This test is analogous to a test of bivariate regression used to assess a dose-response relationship between two 
interval-level variables. When the predictor variable $(X)$ is ordinal level then the interpretation of a dose response is that changes in the outcome variable $(Y)$ between successive values of $X$ be uniform. In the general linear model, $X$ is submitted as a nominallevel variable and specific contrasts are used to ask if the deltas are uniform. When $X$ has three levels, with corresponding $Y$ values $Y_{1}, Y_{2}$, and $Y_{3}$, a single contrast, with one degree of freedom, is used to ask if $Y_{2}$ equals the mean of $Y_{1}$ and $Y_{3}$. A low $p$ value for this contrast indicates substantial deviation from uniformity of the deltas. This analysis assumes only that each ascending class of LV function change is greater than the preceding one, and it is useful for detecting the presence of a systematic relationship between dependent and independent variables while making no assumptions about the quantitative nature of such a relationship.

In the second method, the relationship of changes in LV function to changes in the variables of interest was assessed by linear regression analysis, treating LVEF change as a continuous interval variable, with and without statistical adjustment for effect of treatment group. In the third method, the three LV function change groups were analyzed independently by ANOVA and the Bonferroni multiple comparison test, with the model adjusted to statistically control for any effect of treatment group.

Changes in measured parameters among the three treatment groups were assessed by ANOVA/ Bonferroni, and changes within treatment group by paired $t$ test. LVEF and RVEF class differences among treatment groups were also assessed by contingency table analysis of the rank-ordered EF changes into Decline/No Change, Improved, and Marked Improvement groups. Changes in New York Heart Association (NYHA) class among LV function change groups were assessed by the Spearman rank correlation coefficient. Potential differences within functional change and treatment groups were assessed by Student's paired $t$ test. Differences between baseline values in IDC subjects versus nonfailing controls were assessed by Student's unpaired $t$ test. Baseline data are given with variance estimated as standard deviation, and changes are given with variance estimated as SEM. A two-sided $p$ value $<.05$ was considered to be statistically significant. $p$ values for the ordinal trend test, ANOVA, and linear regression were adjusted for the effect of treatment group.

\section{Results}

\section{Subject Demographics}

Table 1 gives the demographics and other clinical descriptors of the 47 subjects with heart failure from IDC that had complete (baseline and after 6 months of treatment) ventricular function and mRNA ( $n=$ $45)$ or $\beta$-adrenergic receptor protein $(n=36)$ measurements. The subject population is a relatively young (mean age 53 years) heart failure group with
Table 1. Patient demographics $(n=47)$

\begin{tabular}{|c|c|}
\hline Parameter & Mean Value \pm SD \\
\hline Age $(y)$ & $53 \pm 11$ \\
\hline Gender (F/M) & $20 / 27$ \\
\hline LVEF (EF units) & $21.6 \pm 8.2$ \\
\hline RVEF (EF units) & $32.8 \pm 10.8$ \\
\hline Peak $\mathrm{Vo}_{2}(\mathrm{ml} / \mathrm{kg} / \mathrm{min})$ & $16.2 \pm 4.6$ \\
\hline NYHA class (II/III/IV) & $10 / 36 / 1$ \\
\hline Heart rate (beats/min)* & $87.0 \pm 16.8$ \\
\hline Mean arterial pressure $(\mathrm{mm} \mathrm{Hg})^{*}$ & $85.9 \pm 12.8$ \\
\hline Right atrial mean pressure (mm Hg) & $5.9 \pm 4.9$ \\
\hline $\begin{array}{l}\text { Pulmonary artery mean } \\
\text { pressure }(\mathrm{mm} \mathrm{Hg})\end{array}$ & $25.5 \pm 9.2$ \\
\hline $\begin{array}{l}\text { Pulmonary wedge mean } \\
\text { pressure }(\mathrm{mm} \mathrm{Hg})\end{array}$ & $13.6 \pm 7.3$ \\
\hline Cardiac index $\left(1 / \mathrm{min} / \mathrm{m}^{2}\right)$ & $2.44 \pm 0.59$ \\
\hline Stroke volume index $\left(\mathrm{ml} / \mathrm{beat} / \mathrm{m}^{2}\right)$ & $29.2 \pm 9.0$ \\
\hline LV stroke work index $\left(\mathrm{g}-\mathrm{m} / \mathrm{m}^{2}\right)$ & $29.5 \pm 12.2$ \\
\hline Coronary sinus norepinephrine $(\mathrm{pg} / \mathrm{ml})$ & $982 \pm 673$ \\
\hline
\end{tabular}

${ }^{*}$ Measured at the time of catheterization.

moderate symptoms (majority NYHA Class III), severe LV dysfunction (mean LVEF 21.6 EF units), preserved resting hemodynamics (mean cardiac index $2.44 \mathrm{~mL} / \mathrm{min} / \mathrm{m}^{2}$ ), mild volume overload (mean pulmonary wedge pressure $13.6 \mathrm{~mm} \mathrm{Hg}$, mean right atrial mean pressure $5.9 \mathrm{~mm} \mathrm{Hg}$ ), moderate exercise intolerance (mean peak $\mathrm{VO}_{2} 16.2 \mathrm{ml} / \mathrm{kg} / \mathrm{min}$ ), and marked cardiac adrenergic activation (mean coronary sinus norepinephrine $982 \mathrm{pg} / \mathrm{ml}$ ). There were no differences in any baseline demographic measurement between subjects assigned to the three treatment groups.

\section{Baseline Gene Expression Data}

Baseline mRNA and $\beta$-receptor protein data in the 47 IDC subjects are reported elsewhere (8) and consisted of decreases in the mRNA and protein expression of $\beta_{1}$-adrenergic receptors, decreases in the mRNA expression of SRCA and $\alpha$-MyHC genes, and a respective increase or trends for an increase in the mRNA expression of ANP and $\beta$-MyHC.

\section{Effect of Treatment}

Between-Group Changes By treatment group comparison the only statistically significant changes among groups were in LVEF, where by ANOVA the metoprolol and carvedilol groups exhibited greater numerical increases than the placebo group (that were not quite significant after Bonferroni multiple group correction), and peak exercise heart rate, where both $\beta$-blocker groups exhibited greater degrees of reduction (Table 2 ). 
Table 2. Changes in measured parameters by treatment group ( \pm SEM), subjects who had complete mRNA or $\beta$-adrenergic receptor measurements $(n=47)$

\begin{tabular}{|c|c|c|c|c|}
\hline Parameter & $\begin{array}{l}\text { Placebo } \\
(n=14)\end{array}$ & $\begin{array}{l}\text { Metoprolol } \\
\quad(n=14)\end{array}$ & $\begin{array}{l}\text { Carvedilol } \\
(n=19)\end{array}$ & $\begin{array}{l}\text { ANOVA } \\
p \text { Value }\end{array}$ \\
\hline NYHA class (II/III/IV) & $-0.2 \pm 0.2$ & $-0.6 \pm 0.1^{\dagger}$ & $-0.4 \pm 0.1^{\dagger}$ & 0.19 \\
\hline LVEF (EF units) & $4.8 \pm 2.9$ & $13.9 \pm 2.5^{\dagger}$ & $15.4 \pm 3.1^{\dagger}$ & 0.033 \\
\hline RVEF (EF units) & $4.1 \pm 2.1^{\ddagger}$ & $9.5 \pm 3.1^{\dagger}$ & $9.0 \pm 2.8^{\dagger}$ & 0.35 \\
\hline Peak $\mathrm{Vo}_{2}(\mathrm{ml} / \mathrm{kg} / \mathrm{min})$ & $1.6 \pm 1.2$ & $1.4 \pm 1.2$ & $0.4 \pm 1.1$ & 0.75 \\
\hline $\begin{array}{l}\text { Peak exercise heart rate } \\
\text { (beats/min) }\end{array}$ & $-2.8 \pm 5.3$ & $-29.3 \pm 5.8^{*}+$ & $-28.6 \pm 4.7^{*},+$ & 0.005 \\
\hline Resting heart rate (beats/min) & $-8.4 \pm 5.5$ & $-22.0 \pm 4.0^{\dagger}$ & $-17.0 \pm 3.7^{\dagger}$ & 0.12 \\
\hline Mean arterial pressure $(\mathrm{mm} \mathrm{Hg})^{*}$ & $-7.2 \pm 4.2^{\ddagger}$ & $-0.2 \pm 5.0$ & $-1.0 \pm 2.9$ & 0.45 \\
\hline Right artrial mean pressure $(\mathrm{mm} \mathrm{Hg})$ & $1.2 \pm 1.1$ & $-2.1 \pm 1.5$ & $-1.3 \pm 0.9$ & 0.17 \\
\hline $\begin{array}{l}\text { Pulmonary artery mean } \\
\text { pressure }(\mathrm{mm} \mathrm{Hg})\end{array}$ & $-1.8 \pm 1.6$ & $-3.8 \pm 3.1$ & $-5.4 \pm 1.9^{\dagger}$ & 0.56 \\
\hline $\begin{array}{l}\text { Pulmonary wedge mean } \\
\text { pressure }(\mathrm{mm} \mathrm{Hg})\end{array}$ & $-1.0 \pm 1.5$ & $-4.5 \pm 2.9$ & $-4.3 \pm 1.6^{\dagger}$ & 0.47 \\
\hline Cardiac index $\left(1 / \mathrm{min} / \mathrm{m}^{2}\right)$ & $-0.10 \pm 0.19$ & $0.03 \pm 0.23$ & $0.20 \pm 0.15$ & 0.50 \\
\hline $\begin{array}{l}\text { Stroke volume index } \\
\left(\mathrm{ml} / \mathrm{beat} / \mathrm{m}^{2}\right)\end{array}$ & $3.0 \pm 2.1$ & $9.2 \pm 2.6^{\dagger}$ & $10.3 \pm 3.1^{\dagger}$ & 0.24 \\
\hline LV stroke work index $\left(\mathrm{g}-\mathrm{m} / \mathrm{m}^{2}\right)$ & $0.7 \pm 2.8$ & $10.3 \pm 2.4^{\dagger}$ & $11.1 \pm 3.7^{\dagger}$ & 0.09 \\
\hline Arterial norepinephrine $(\mathrm{pg} / \mathrm{ml})$ & $-432 \pm 175^{\dagger}$ & $-351 \pm 268$ & $152 \pm 91$ & 0.19 \\
\hline $\begin{array}{l}\text { Coronary sinus } \\
\text { norepinephrine }(\mathrm{pg} / \mathrm{ml})\end{array}$ & $-400 \pm 153^{\dagger}$ & $-222 \pm 219$ & $-60 \pm 148$ & 0.38 \\
\hline
\end{tabular}

\begin{tabular}{|c|}
\hline $\begin{array}{l}\text { Gene Expression } \\
\text { (Molecules mRNA } \times \\
10^{5} / \mu \text { g Total RNA) }\end{array}$ \\
\hline$\beta_{1}$-Adrenergic receptor $\left(\beta_{1} \mathrm{AR}\right)$ \\
\hline$\beta_{2}$-Adrenergic receptor $\left(\beta_{2} \mathrm{AR}\right)$ \\
\hline Atrial natriuretic peptide (ANP) \\
\hline SR Ca ${ }^{2+}$ ATPase-2a (SRCA) \\
\hline$\alpha$-Myosin heavy chain ( $\alpha$-MyHC) \\
\hline$\beta$-Myosin heavy chain $(\beta$-MyHC) \\
\hline Total myosin heavy chain \\
\hline$\% \alpha-\mathrm{MyHC}$ \\
\hline $\begin{array}{l}\beta \text {-Adrenergic Receptor } \\
\text { Protein (fmol/mg) }\end{array}$ \\
\hline $\begin{array}{l}\text { Total } \beta \text {-Adrenergic } \\
\text { receptor density }\end{array}$ \\
\hline$\beta_{1}$-Adrenergic receptor density \\
\hline$\beta_{2}$-Adrenergic receptor density \\
\hline$\% \beta_{1}$-Adrenergic receptors \\
\hline
\end{tabular}

\begin{tabular}{cccc}
$\begin{array}{l}\text { Placebo } \\
(n=13)\end{array}$ & $\begin{array}{c}\text { Metoprolol } \\
(n=14)\end{array}$ & $\begin{array}{c}\text { Carvedilol } \\
(n=18)\end{array}$ & $p$ \\
\hline $0.31 \pm 0.42$ & $0.15 \pm 0.18$ & $0.07 \pm 0.40$ & 0.90 \\
$0.35 \pm 0.22$ & $0.18 \pm 0.18$ & $0.17 \pm 0.58$ & 0.95 \\
$39.0 \pm 17.0^{\dagger}$ & $-12.5 \pm 8.7$ & $-35.8 \pm 12.2^{\dagger}$ & 0.31 \\
$10.0 \pm 6.2$ & $4.4 \pm 4.0$ & $3.9 \pm 4.5$ & 0.64 \\
$0.2 \pm 2.2$ & $4.1 \pm 2.0^{\ddagger}$ & $0.5 \pm 1.4$ & 0.24 \\
$11.7 \pm 12.0$ & $-26.5 \pm 15.6$ & $9.7 \pm 13.3$ & 0.11 \\
$11.9 \pm 11.2$ & $-23.3 \pm 14.3$ & $10.3 \pm 13.4$ & 0.13 \\
$0.7 \pm 1.5$ & $4.7 \pm 2.4^{\ddagger}$ & $0.5 \pm 1.1$ & 0.15
\end{tabular}

\begin{tabular}{cccc}
$\begin{array}{c}\text { Placebo } \\
(n=13)\end{array}$ & $\begin{array}{c}\text { Metoprolol } \\
(n=10)\end{array}$ & $\begin{array}{c}\text { Carvedilol } \\
(n=13)\end{array}$ & $p$ \\
\hline $13.3 \pm 9.1$ & $24.5 \pm 5.7^{\dagger}$ & $21.5 \pm 9.3^{\dagger}$ & 0.64 \\
$16.1 \pm 11.2$ & $19.1 \pm 6.9^{\dagger}$ & $19.0 \pm 7.8^{\dagger}$ & 0.96 \\
$-2.8 \pm 3.5$ & $5.4 \pm 5.2$ & $2.5 \pm 2.8$ & 0.31 \\
$16.9 \pm 6.8^{\dagger}$ & $4.9 \pm 9.4$ & $2.6 \pm 5.7$ & 0.28
\end{tabular}


Within-Group Changes There were multiple significant $(p<0.05)$ changes in the measured parameters within treatment groups, as presented in Table 2. The placebo group exhibited decreases in ANP mRNA abundance and coronary sinus or arterial norepinephrine, and an increase in $\beta_{1}$-adrenergic receptors percent. The metoprolol group had increases in total $\beta$ - and $\beta_{1}$-adrenergic receptor densities, LVEF, RVEF, stroke volume, and LV stroke work indices, and decreases in peak exercise heart rate, NYHA class, and resting heart rate. In the carvedilol group, there were increases in total $\beta$ - and $\beta_{1}$-adrenergic receptor density, LVEF, RVEF, stroke volume, and LV stroke work indices, and decreases in peak exercise heart rate, NYHA class, ANP mRNA abundance, pulmonary wedge mean pressure, pulmonary artery mean pressure, and resting heart rate.

Changes in Hemodynamics, Cardiac Adrenergic Drive,

Functional Capacity, NYHA Class, and RVEF by LV

Function Change Group or by Linear Regression Analysis of LVEF Change

Between-Group Changes Table 3 gives the changes in LVEF, RVEF, hemodynamics, and other measured responses in the three LVEF change groups for subjects who had complete mRNA measurements. As shown in Table 3, LVEF by definition and RVEF data exhibit sequential increases among the three LV function change groups. The only other hemodynamic variable listed in Table 3 that had a significant change by ordinal trend test was pulmonary artery mean pressure. NYHA functional class did not differ among groups by ordinal trend test $(p=0.42)$ or Spearman rank correlation coefficient $(p=0.16)$. By ANOVA, pulmonary wedge pressure and pulmonary artery mean pressure exhibit decreases in the Marked Improvement group as compared to the Improved or Decline/No Change groups.

With linear regression analysis using change in LVEF as a continuous variable, RVEF change was positively related $(r=0.51, p=0.001)$, and pulmonary artery mean pressure $(r=-0.37, p=0.029)$ was negatively related. No other hemodynamic changes were significantly related to change in LVEF.

Within-Group Changes The Decline/No Change group exhibited a decrease in heart rate and an increase in stroke volume index. The Improved group

Table 3. Changes in LVEF, RVEF, hemodynamics, coronary sinus norepinephrine, and peak Vo, in three $\mathrm{LV}$ function change groups, subjects with complete mRNA measurements $(n=15$ /group)

\begin{tabular}{|c|c|c|c|c|}
\hline Parameter (Units) & Decline/No Change & Improved & Marked Improvement & $\begin{array}{l}p \text { Value, Ordinal } \\
\text { Trend Test }\end{array}$ \\
\hline LVEF (EF units) & $-2.2 \pm 1.1^{\S}$ & $12.2 \pm 0.9^{*}+$ & $25.5 \pm 1.8^{*, \#, \dagger}$ & 0.0001 \\
\hline RVEF (EF units) & $-0.2 \pm 1.9$ & $10.2 \pm 2.3^{*},+$ & $13.5 \pm 3.1^{*}+$ & 0.0008 \\
\hline Heart rate (BPM) & $-14.2 \pm 5.5^{+}$ & $-15.4 \pm 3.7^{\dagger}$ & $-19.9 \pm 4.8^{\dagger}$ & 0.91 \\
\hline $\begin{array}{l}\text { Mean arterial pressure } \\
(\mathrm{mm} \mathrm{Hg})\end{array}$ & $-3.8 \pm 3.8$ & $-2.1 \pm 4.7$ & $-1.5 \pm 4.1$ & 0.99 \\
\hline $\begin{array}{l}\text { Right atrial mean pressure } \\
(\mathrm{mm} \mathrm{Hg})\end{array}$ & $0.2 \pm 1.2$ & $-0.1 \pm 1.2$ & $-2.2 \pm 1.3$ & 0.61 \\
\hline $\begin{array}{l}\text { Pulmonary artery mean } \\
\text { pressure }(\mathrm{mm} \mathrm{Hg})\end{array}$ & $-2.1 \pm 2.1$ & $0.3 \pm 2.0$ & $-9.9 \pm 2.1^{*, \#,+}$ & 0.04 \\
\hline $\begin{array}{l}\text { Pulmonary wedge mean } \\
\text { pressure (mm Hg) }\end{array}$ & $-1.3 \pm 1.7$ & $-0.2 \pm 1.8$ & $-8.4 \pm 2.3^{\#, \dagger}$ & 0.07 \\
\hline Cardiac index $\left(1 / \mathrm{min} / \mathrm{m}^{2}\right)$ & $0.02 \pm 0.19$ & $-0.14 \pm 0.17$ & $0.26 \pm 0.20$ & 0.62 \\
\hline $\begin{array}{l}\text { Stroke volume index } \\
\left(\mathrm{ml} / \mathrm{beat} / \mathrm{m}^{2}\right)\end{array}$ & $7.5 \pm 3.1^{\dagger}$ & $5.4 \pm 2.3^{\dagger}$ & $11.1 \pm 3.6^{\dagger}$ & 0.83 \\
\hline $\begin{array}{l}\text { LV stroke work index } \\
\left(\mathrm{g}-\mathrm{m} / \mathrm{m}^{2}\right)\end{array}$ & $6.1 \pm 2.8^{\S}$ & $3.3 \pm 2.5$ & $13.9 \pm 4.2^{\dagger}$ & 0.41 \\
\hline $\begin{array}{l}\text { Coronary sinus } \\
\text { norepinephrine }(\mathrm{pg} / \mathrm{ml})\end{array}$ & $-258 \pm 168$ & $-149 \pm 171$ & $-206 \pm 209$ & 0.72 \\
\hline Peak $\mathrm{Vo}_{2}(\mathrm{ml} / \mathrm{kg} / \mathrm{min})$ & $1.0 \pm 1.5$ & $0.8 \pm 1.4$ & $1.3 \pm 0.9$ & 0.72 \\
\hline
\end{tabular}

${ }^{*} p<.05$ versus Decline/No Change (ANOVA).

${ }^{\#} p<.05$ versus Improved (ANOVA).

${ }^{\dagger} p<.05$ within group (paired $t$-test).

${ }^{s_{p}}<<.10$ within group (paired $t$-test).

Ordinal trend test $p$ values are adjusted for treatment group. 
had increases in LVEF, RVEF, and stroke volume index, and a decrease in heart rate. The Marked Improvement group exhibited an increase in LVEF, RVEF, stroke volume index, and left ventricular stroke work index, and a decrease in pulmonary wedge mean pressure, pulmonary arterial mean pressure, and heart rate.

Changes in mRNA Expression by LV Function Change Group or Linear Regression Analysis of LVEF Change

Between-Group Changes Figures 1 through 4 give the changes in mRNA expression in the LV function change groups. As shown in Figure 1, there were no changes in $\beta$-adrenergic receptor mRNA expression associated with changes in left ventricular function. There were also no changes in $\beta_{1}$ - or $\beta_{2}$-adrenergic mRNA abundance within any of the function change groups. Similarly, Figure 2 demonstrates that SRCA and ANP gene expression is not different among the different functional groups.

In contrast, there were changes in both $\alpha$ - and $\beta$-MyHC that incrementally increased with the function change groups (Fig. 3). Across the three LV function change groups, by adjusted ordinal trend test, there were ascending increases in $\alpha-\mathrm{MyHC}(p=0.012)$ and ascending decreases in $\beta$-MyHC $(p=0.007)$. A similar pattern of ascending decrease was shown for total MyHC (Fig. 4, $p=0.014$ ). Because of the progressive increases in $\alpha$-MyHC and decreases in $\beta$ MyHC gene expression with increasing LV and RV function, there was also a progressive increase in the percent of $\alpha-\mathrm{MyHC} /$ total MyHC as function improved (Fig. 4, ordinal trend test $p=0.026$ ).

For linear regression analysis using change in LVEF as a continuous variable, LVEF change was positively related to change in $\alpha$-MyHC steady-state abundance $(r=0.34, p=0.023)$ and to percent $\alpha$-MyHC $(r=0.29, p=0.045)$, and negatively related to change in $\beta$-MyHC $(r=-0.43, p=0.002)$, and total MyHC $(r=-0.42, p=0.003)$. No other changes in mRNA expression were significantly related to change in LVEF.

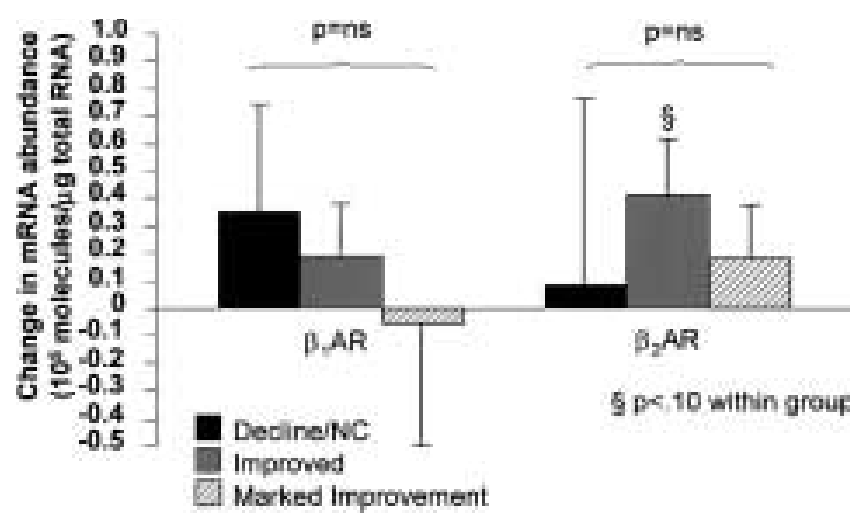

Fig. 1. Changes in $\beta_{1}$ - and $\beta_{2}$-adrenergic receptor (AR) mRNA abundances by three LV function change group. $p$ values refer to expression-response analysis. ANOVA was also nonsignificant for both mRNAs.

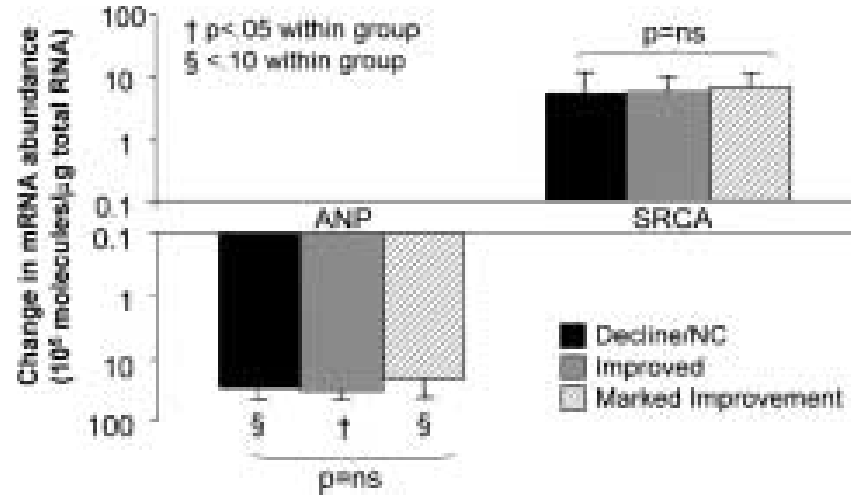

Fig. 2. Changes in ANP and SRCA mRNA abundances by three LV function change group. Note $y$ axis is logarithmic. $p$ values refer to expression-response analysis. ANOVA was also nonsignificant for both mRNAs.

Within-Group Changes Within function change groups, the Declined/No Change group exhibited an increase $(p<0.05$ by paired $t$-test) in $\beta$-MyHC and total MyHC, and a trend $(p<0.10)$ for a decrease in ANP mRNA expression. The Improved group had an increase in $\alpha$-MyHC and percent $\alpha$-MyHC plus a trend for an increase in $\beta_{2}$-receptor, and a decrease in ANP mRNA expression. The Marked Improvement group exhibited trends in increases in $\alpha$-MyHC and percent $\alpha$-MyHC, and trends for decreases in $\beta$-MyHC, total MyHC, and ANP mRNA expression.

Changes in $\beta$-Adrenergic Receptor Protein Expression by $L V$ Function Change Group or Linear Regression Analysis of LVEF Change

Between-Group Changes As shown in Figure 5, by expression-response analysis, there were no differences in the expression of total $\beta-, \beta_{1}{ }^{-}$, or $\beta_{2^{-}}$ adrenergic receptor protein expression among the three function change groups constructed for the

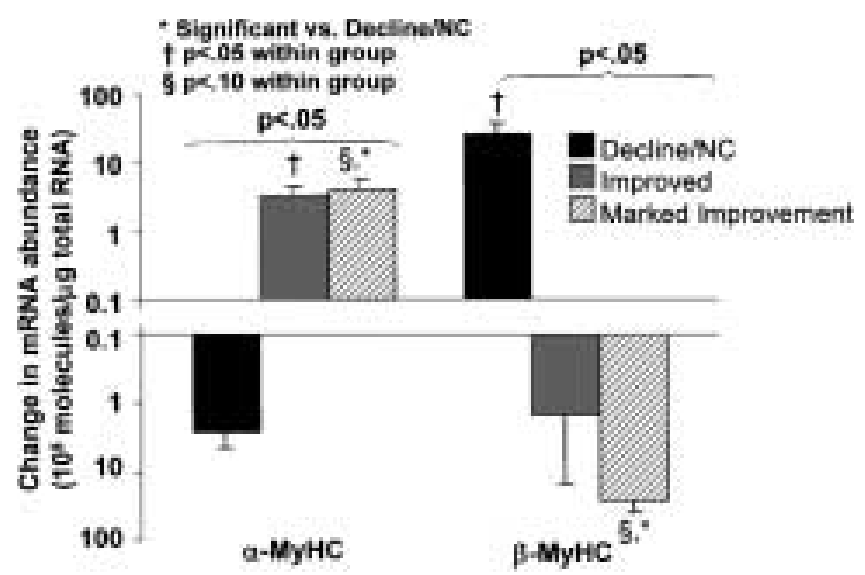

Fig. 3. Changes in $\alpha$ - and $\beta$-MyHC mRNA abundances by three LV function change groups. Note $y$ axis is logarithmic. $p$ values refer to ordinal trend test. ANOVA $p$ values were 0.027 for $\alpha$-MyHC and 0.022 for $\beta$-MyHC. 


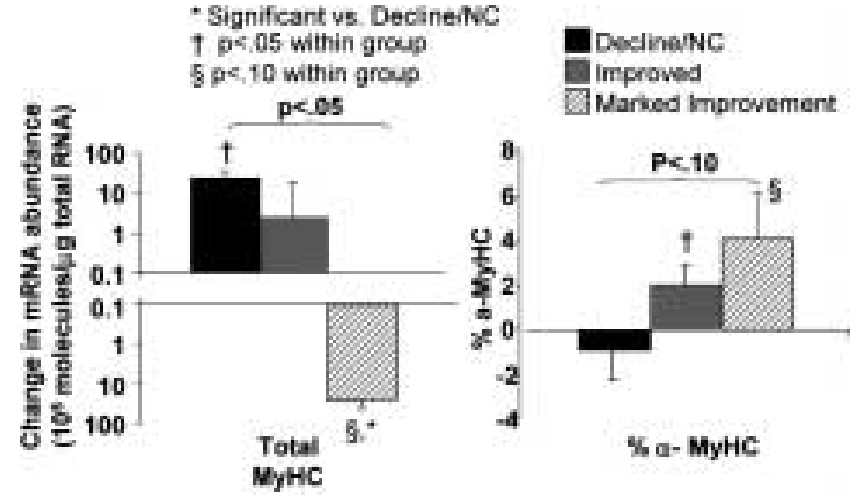

Fig. 4. Changes in total ( $\alpha$ - plus $\beta$-) MyHC mRNA abundance and in percent $\alpha$-MyHC/total MyHC by three LV function change groups. Note $y$ axis is logarithmic for total MyHC. $p$ values refer to expression-response analysis. ANOVA $p$ values are 0.034 for total MyHC and 0.076 for percent $\alpha$-MyHC.

36 subjects with complete $\beta$-adrenergic receptor protein measurements. For $\beta_{2}$-receptors, by ANOVA the Improved group had an increased level of expression compared to the Decline/No Change or Marked Improvement group. There were no significant differences between LV function change and receptor protein expression using LVEF change as an ordinal or continuous variable for any receptor type.

Within-Group Changes As shown in Figure 5, the Decline/No Change and Marked Improvement groups exhibited similar within-group increases in $\beta_{1^{-}}$and total $\beta$-adrenergic receptor densities, and the Improved group exhibited an increase in $\beta_{2}$-adrenergic receptor protein expression that was not present in the Decline/No Change or Marked Improvement groups.

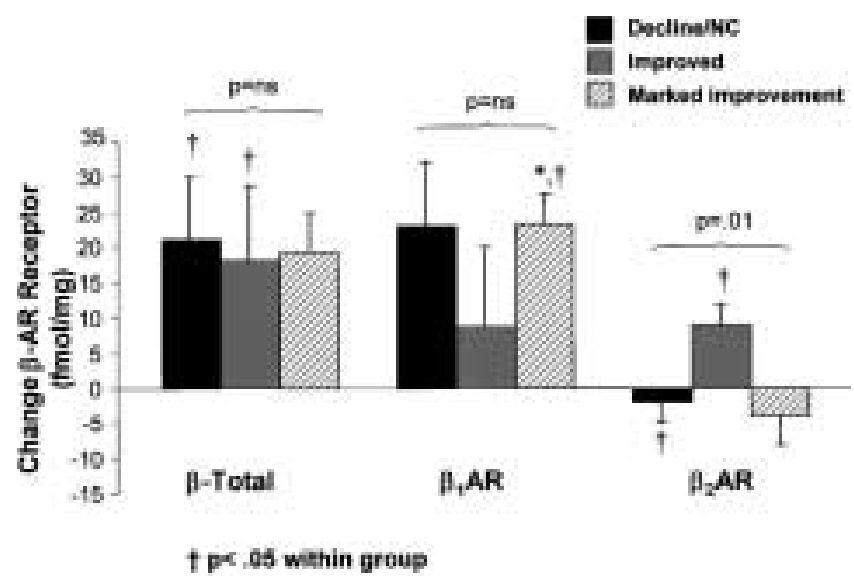

Fig. 5. Changes in $\beta_{1^{-}}$and $\beta_{2}$-AR protein in three LV function change groups. $N=11$ for Decline/No Change, $N=13$ for Improved, and $N=12$ for Marked Improvement. $p$ values refer to expression-response analysis. Corrected ANOVA $p$ values are nonsignificant for total $\beta$ - and $\beta_{1}$-receptor densities, and 0.025 for $\beta_{2}$-receptor density.

\section{Coordinate Changes in $\alpha-, \beta-M y H C$ mRNA Expression}

Figure 6 illustrates the changes in $\beta$-MyHC versus $\alpha$-MyHC, SRCA, ANP, and $\beta_{1}$-adrenergic receptor mRNA abundance across all subjects and all EF changes. As can be seen, changes in $\beta$-MyHC and $\alpha$ $\mathrm{MyHC}$ are coordinate, with a decreases in $\beta$-MyHC related to increases in $\alpha$-MyHC. In contrast, changes in $\beta$-MyHC are unrelated to two other genes ordinarily considered to be part of the fetal gene program, ANP and SRCA. Changes in $\beta$-MyHC are also unrelated to changes in $\beta_{1}$ - or $\beta_{2}$-adrenergic receptor mRNA (data not shown).

\section{Discussion}

The most common cause of heart failure in the United States is secondary or primary dilated cardiomyopathy, phenotypically characterized by hypertrophy, ventricular chamber dilatation, and decreased contractile function (25). The alterations in gene expression responsible for dilated cardiomyopathy phenotypes remain unidentified. In terms of contractile dysfunction, leading contenders include changes in components of $\beta$-adrenergic signal transduction, calciumhandling mechanisms, and contractile proteins (2). For ventricular pathologic hypertrophy, a net increase in contractile protein and sarcomeres through the activation of myocardial growth fetal genes that include $\beta$-MyHC has been described $(6,7,26-29)$. The induction of pathologic hypertrophy and the development of contractile dysfunction are interrelated, because the increased expression of $\beta$-MyHC and associated decreased expression of $\alpha$-MyHC and other genes such as SRCA $(28,29)$ decrease systolic and diastolic function (2).

In this study, we utilized the substantial changes in the dilated cardiomyopathy phenotype that occur variably in chronic heart failure patients treated with $\beta$-blockade or placebo to create a dynamic phenotypic model suitable for investigation of the molecular basis of myocardial failure. The advantage of such a model is considerable, because candidate genes whose expression is not associated with phenotypic modification can be distinguished and eliminated from consideration. Improvement in dilated cardiomyopathy phenotype in response to $\beta$ blocker therapy involves an increase in velocity of ventricular pressure development (16), an upward and leftward shift in depressed left (16) and right (20) ventricular function curves indicative of improved intrinsic systolic function, and a decrease in ventricular volume (16-21) and mass $(16,17,21)$. Primary dilated cardiomyopathy-IDC-was chosen for investigation because IDC is relatively common and its gene expression profile is similar to more common secondary cardiomyopathies $(6,25,30)$. The high response rate of IDC to $\beta$-blockade plus spontaneous improvement in some subjects in the placebo group led to substantial numbers of subjects exhibiting improvement in LVEF, including 15 subjects 

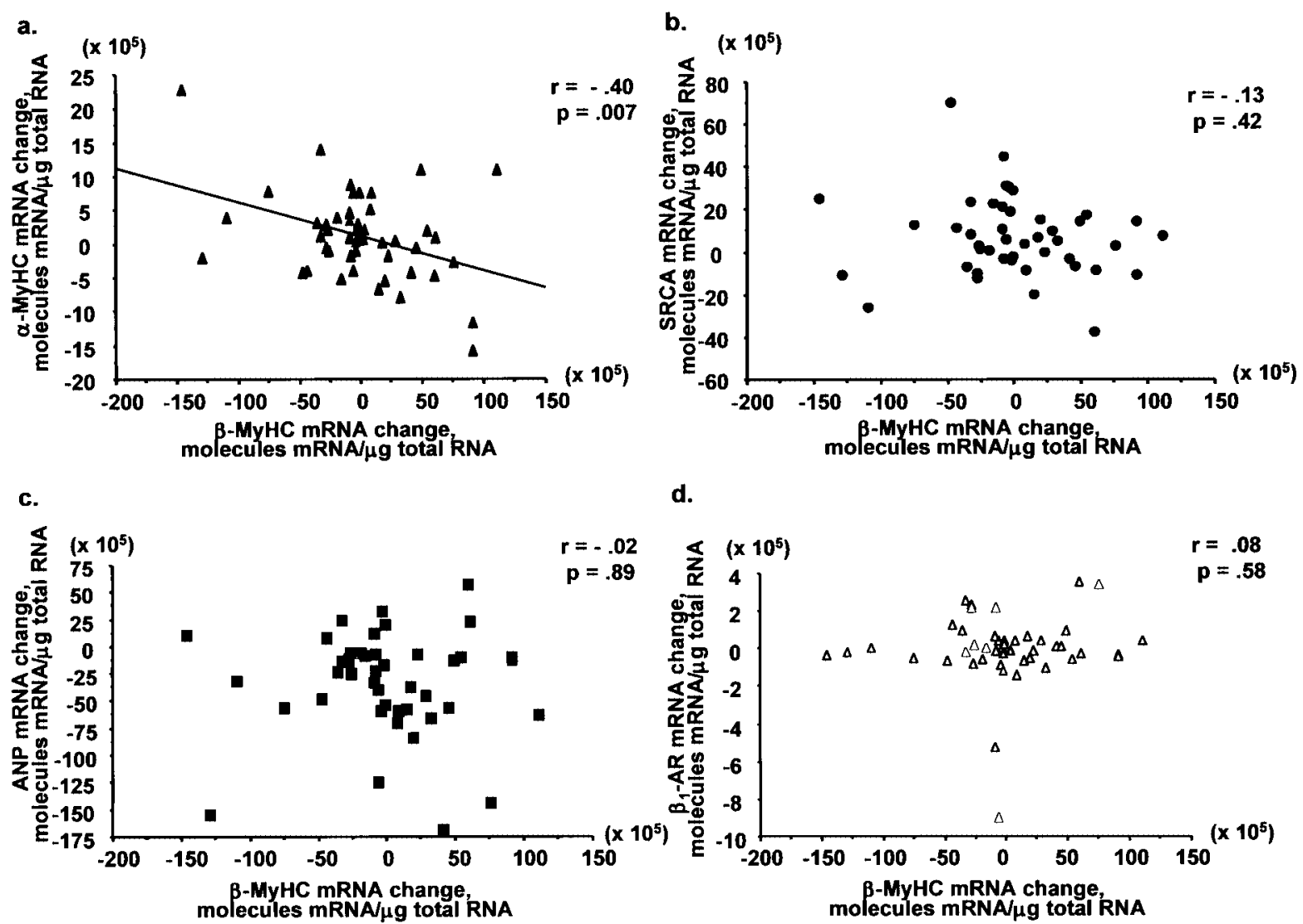

d.

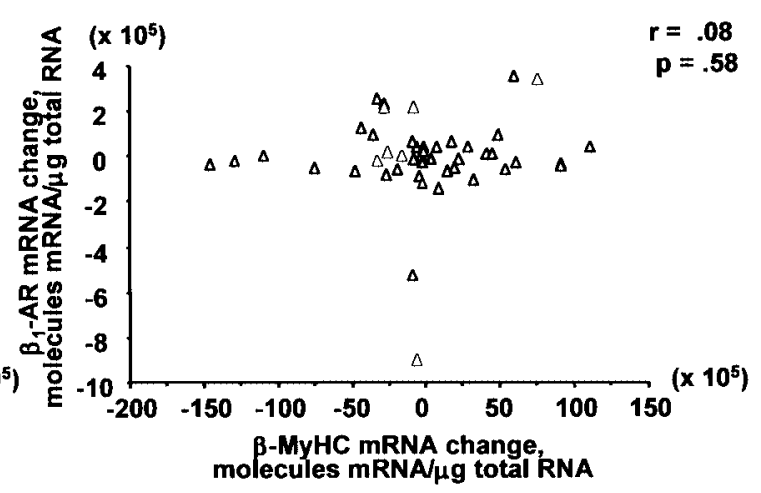

Fig. 6. (A) Changes between baseline and 6 months in $\alpha$-MyHC expression versus $\beta$-MyHC mRNA abundance for all subjects. (B) Changes in SRCA versus $\beta$-MyHC mRNA abundance. (C) Changes in ANP versus $\beta$-MyHC mRNA abundance. (D) Changes in $\beta_{1}$-adrenergic receptor versus $\beta$-MyHC mRNA abundance.

with a change of more than 17 EF units, a degree of improvement that amounts to normalization or near normalization of left ventricular function. LVEF was used to measure systolic contractile function because the test is readily available and is standardized, and because LVEF is less load-dependent than standard hemodynamic measurements (31). Moreover, across the three LV function change groups analyzed by ordinal trend test, there were no changes in LV loading conditions that might have confounded the analysis. That is, mean arterial pressure did not change significantly across the three groups, and the trend toward a lower mean pulmonary wedge pressure in the Marked Improvement group would tend to lower, not increase, ejection fraction. Thus, in this study LVEF change should accurately reflect changes in LV systolic function. Because the ejection fraction calculation is heavily influenced by end-diastolic volume, in dilated cardiomyopathies LVEF is also an estimate of the degree of chamber dilatation or remodeling (32).

The IDC population investigated in this study exhibited the gene expression abnormalities previously reported by our $(1,4,6-8,30)$ and other $(3,5,15)$ laboratories. These changes include components of fetal gene program induction (increased mRNA ex- pression of ANP and $\beta$-MyHC, decreased expression of $\alpha$-MyHC and SR $\mathrm{Ca}^{2+}$ ATPase), and the consequences of chronic adrenergic activation (downregulation in $\beta_{1}$-receptor mRNA and protein expression). The question addressed by this study is which of these gene expression abnormalities most closely relates to modifications in dilated cardiomyopathy phenotype measured over a 6-month period in all subjects, regardless of treatment. Because the nature of the relationship between gene expression and any related LVEF change is uncertain and because EF change is unlikely to be linearly related to changes in intrinsic function or degree of pathologic hypertrophy, several types of statistical models were employed.

The results of this study indicate that changes in the mRNA expression of two genes whose regulation is coordinately linked (33), $\alpha$ - and $\beta$-MyHC, are selectively associated with modifications in ventricular systolic function and remodeling. The expression of $\alpha$-MyHC exhibited a statistically significant progressive increase across ascending LV function change groups, from a negative value in the Decline/No Change group to increasingly positive values in the Improved and Marked Improvement groups. Conversely, $\beta$-MyHC gene expression exhibited a decrease from a positive change value in 
the Decline/No Change group to progressively more negative values in the Improved and Marked Improvement groups. If translated into proportional changes in protein expression (34), such changes in MyHC isogene expression could potentially improve intrinsic systolic and diastolic function (35) because the $\alpha$-MyHC isoform has a much higher myosin ATPase activity than the $\beta$-isoform, resulting in a faster velocity of shortening and rate of crossbridge cycling $(26,27,35)$. In rodent $(35-37)$ and rabbit (38) models of pathologic hypertrophy and myocardial failure, coordinate decreases in $\alpha$-MyHC and increases in $\beta$-MyHC mRNA and protein expression are associated with a reduction in velocity of shortening and other measures of systolic function.

Although in the current study the small amounts of starting material precluded measurement of $\alpha$ and $\beta$-MyHC protein, in gram quantities of failing explanted human left ventricular myocardium changes in gel electrophoresis-measured MyHC isoforms are directionally similar to changes in mRNA (34). However, in human ventricular myocardium the absolute expression of $\alpha$-MyHC protein is much less than its mRNA expression $(32,39)$. For example, in nonfailing left ventricles $\alpha$-MyHC protein expression is $5-10 \%$ of total $\mathrm{MyHC}$, versus $25-30 \%$ for mRNA (34). Although the protein expression of $\alpha$ MyHC decreases to near zero in failing hearts $(34,39)$, it is unclear if such a small absolute change can account for a decrease in intrinsic contractile function. In favor of such small changes being functionally significant are the observations that (1) in model systems small amounts $(\sim 10 \%)(40)$ or changes (37) of $\alpha$-MyHC have relatively large effects on force development and (2) recent data from our laboratory demonstrating that human cardiac $\alpha$ MyHC has greater (relative to $\beta$-MyHC) specific myosin and myofibrillar ATPase activities than has been in reported in rat or rabbit hearts (K. Nunley et al., submitted). Thus an increase in percent $\alpha \mathrm{MyHC}$ isoform expression is a molecular change that could causally relate to improved function. Alternatively, changes toward normal in MyHC isoforms could simply be a molecular marker of de-induction of the fetal gene program, with other components accounting for the actual improvement in function.

Similarly, the progressive decrease in total MyHC $(\alpha$-MyHC $+\beta$-MyHC) gene expression with increasing LVEF (and decreasing end diastolic volume) (32) is a molecular measure of reverse remodeling; MyHC is a major structural protein of the myocardial contractile element (41). As a molecular index of reverse remodeling, in the current study changes in total MyHC or $\beta$-MyHC appeared to be superior to the indirect hypertrophic marker ANP, because total or $\beta$-MyHC but not ANP expression exhibited an incremental decline as remodeling progressively decreased. ANP gene expression decreased or tended to decrease in all LV function/diastolic volume change groups, indicating that this molecular phenotypic marker was nonspecifically responding to the general treatment of chronic heart failure. This was confirmed by significant reductions in ANP gene expression within the placebo and carvedilol treatment groups.

There were also no changes in $\beta_{1}$-adrenergic receptor gene or protein expression or in SRCA gene expression that were systematically associated with changes in ventricular function. In subjects treated with $\beta$-blocking agents SRCA increases selectively in subjects who exhibit an improvement in LVEF, but spontaneous LVEF responders treated with placebo do not exhibit increases in SRCA (8). Therefore, in the current analysis that included subjects treated with or without $\beta$-blockade, there was no relationship between change in SRCA gene expression and change in phenotype. Total $\beta$ - and $\beta_{1^{-}}$ adrenergic receptor protein density increased or tended to increase in all three LV function change groups. This indicates that changes in these molecular myocardial dysfunction candidates can occur in response to heart failure medical treatment, unrelated to modification of ventricular function or remodeling. This was confirmed by significant increases in total $\beta$ - and $\beta_{1}$-adrenergic receptor protein density within the metoprolol and carvedilol treatment groups.

In this study, $\alpha$-MyHC and $\beta$-MyHC were coordinately and reciprocally regulated across all changes in LV function. In contrast, two other genes ordinarily considered to be part of the fetal gene program, ANP and SRCA, were not coordinately regulated with $\beta$-MyHC. Coordinate, reciprocal regulation of cardiac MyHC isoforms in a variety of settings, including pathologic hypertrophy and failure, is well known in small animal models (42) and our data extend these findings to the human heart. The dissociation of regulation of $\beta$-MyHC from SRCA and ANP indicates that fetal gene regulation is complex, and may be individualized for $\mathrm{MyHC}$ isoforms versus other members of this program.

In summary, the data presented in this study indicate that in chronic heart failure patients with a dilated cardiomyopathy phenotype changes in MyHC isogene expression measured in septal endomyocardial biopsy material are closely associated with modification in left ventricular function and chamber remodeling. These associations are specific for MyHC isoform expression, and are not observed for several other molecular changes previously shown to be present in the failing human heart. These observations suggest that modulation of MyHC isoforms may be a therapeutic target for drug development in chronic heart failure, particularly because such treatment should result in cardiac specific effects.

\section{Acknowledgments}

This investigation was sponsored by NIH Grants 1R01 HL48013 from the NHLBI, M01-RR00051 and M01-RR00064 from the National Center for Research 
Resources, and by GlaxoSmithKline Company. The authors are grateful to Laurel Hunter for her assistance in manuscript and figure preparation.

\section{Disclosures}

Drs Gilbert, Abraham, and Bristow have served as paid consultants to Glaxo SmithKline, and Dr Bristow has been a paid consultant for AstraZeneca. Dr Bristow is a founder, officer, and stockholder in Myogen, which owns a license to aspects of the current study that are covered in a patent application.

\section{References}

1. Feldman AM, Ray PA, Silan CM, Mercer JA, Minobe W, Bristow MR. (1991) Selective gene expression in failing human heart. Quantification of steady-state levels of messenger RNA in endomyocardial biopsies using the polymerase chain reaction. Circulation 83: 1866-1872.

2. Bristow MR. (1998) Why does the myocardium fail? New insights from basic science. Lancet 352(suppl I): 8-14.

3. Ungerer M, Böhm M, Elce JS, Erdmann E, Lohse MJ. (1993) Altered expression of $\beta$-adrenergic receptor kinase and $\beta_{1^{-}}$adrenergic receptors in the failing human heart. Circulation 87: 454-463.

4. Bristow MR, Minobe WA, Raynolds MV, et al. (1993) Reduced $\beta_{1}$ receptor messenger RNA abundance in the failing human heart. J. Clin. Invest. 92: 2737-2745.

5. Mercadier JJ, Lompre AM, Duc P, et al. (1990) Altered sarcoplasmic reticulum Ca-ATPase gene expression in the human ventricle during end-stage heart failure. J. Clin. Invest. 85: 305-309.

6. Nakao K, Minobe WA, Roden RL, Bristow MR, Leinwand LA. (1997) Myosin heavy chain gene expression in human heart failure. J. Clin. Invest. 100: 2362-2370.

7. Lowes BD, Minobe WA, Abraham WT, et al. (1997) Changes in gene expression in the intact human heart: down-regulation of $\alpha$-myosin heavy chain in hypertrophied, failing ventricular myocardium. J. Clin. Invest. 100: 2315-2324.

8. Lowes BD, Gilbert EM, Abraham WT, et al. (2002) Myocardial gene expression in dilated cardiomyopathy treated with beta-blocking agents. N. Engl. J. Med. 346: 1357-1365.

9. Lopau K, Mark J, Schramm L, Heidbreder E, Wanner C. (2000) Hormonal changes in brain death and immune activation in the donor. Transplant. Int. 13: S282-S285.

10. Heilbrunn SM, Shah P, Bristow MR, Valantine HA, Ginsburg R, Fowler MB. (1989) Increased $\beta$-receptor density and improved hemodynamic response to catecholamine stimulation during long-term metoprolol therapy in heart failure from dilated cardiomyopathy. Circulation 79: 483-490.

11. Gilbert EM, Abraham WT, Olsen S, et al. (1996) Comparative hemodynamic, left ventricular functional, and antiadrenergic effects of chronic treatment with metoprolol versus carvedilol in the failing heart. Circulation 94: 2817-2825.

12. Ladenson PW, Sherman SI, Baughman KL, Ray PE, Feldman AM. (1992) Reversible alterations in myocardial gene expression in a young man with dilated cardiomyopathy and hypothyroidism. Proc. Natl. Acad. Sci. U.S.A. 89: 5251-5255.

13. Adolph EA, Subramanian A, Cserjesi P, Olson EN, Robbins J. (1993) Role of myocyte-specific enhancer-binding factor (Mef-2) in transcriptional regulation of the $\alpha$-cardiac myosin heavy chain gene. J. Biol. Chem. 268: 5349-5352.

14. Wang AM, Doyle MV, Mark DF. (1989) Quantitation of mRNA by the polymerase chain reaction. Proc. Natl. Acad. Sci. U.S.A. 86: 9717-9721.

15. Engelhardt S, Bohm M, Erdmann E, Lohse MJ. (1996) Analysis of beta-receptor mRNA levels in human ventricular biopsy specimens by quantitative polymerase chain reactions: progressive reduction of beta 1-adrenergic receptor mRNA in heart failure. J. Am. Coll. Cardiol. 27: 146-154.
16. Eichhorn EJ, Bristow MR. (1996) Medical therapy can improve the biologic properties of the chronically failing heart: a new era in the treatment of heart failure. Circulation 94: 2285-2296.

17. Hall SA, Cigarroa CG, Marcoux L, Risser RC, Grayburn PA, Eichhorn EJ. (1995) Time course of improvement in left ventricular function, mass, and geometry in patients with congestive heart failure treated with $\beta$-adrenergic blockade. J. Am. Coll. Cardiol. 5: 1154-1161.

18. Quaife RA, Gilbert EM, Christian PE, et al. (1996) Effects of carvedilol on systolic and diastolic left ventricular performance in idiopathic dilated cardiomyopathy. Am. J. Cardiol. 78: 779-784.

19. Doughty RN, Whalley GA, Gamble G, MacMahon S, Sharpe N. (1996) Left ventricular remodeling with carvedilol in patients with congestive heart failure due to ischemic heart disease. J. Am. Coll. Cardiol. 29: 1060-1066.

20. Quaife RA, Christian PE, Gilbert EM, Datz FL, Volkman K, Bristow MR. (1998) Effects of carvedilol on right ventricular function in chronic heart failure. Am. J. Cardiol. 81: 247-250.

21. Lowes BD, Gill WT, Larrain JR, Robertson AD, Bristow MR, Gilbert EM. (1999) Effects of carvedilol on left ventricular mass, chamber geometry and mitral regurgitation in chronic heart failure. Am. J. Cardiol. 83: 1201-1205.

22. Cintron G, Johnson G, Francis G, Cobb F, Cohn JN. (1993) Prognostic significance of serial changes in left ventricular ejection fraction in patients with congestive heart failure. Circulation 87(suppl VI): VI-17-VI-23.

23. Cetta F, Michels VV. (1995) The natural history and spectrum of idiopathic dilated cardiomyopathy, including HIV and peripartum cardiomyopathy. Curr. Opin. Cardiol. 10: 332 338.

24. Zaret BL, Wackers FJ. (1991) Measurement of right ventricular function. In Gerson MC, ed. Cardiac Nuclear Medicine, 2nd ed. New York: McGraw-Hill.

25. Bristow MR, Mestroni L, Bohlmeyer T, Gilbert EM. (2001) Dilated cardiomyopathies. In Fuster V, Alexander RW, O'Rourke RA, eds. Hurst's the Heart, Volume 2, 10th ed. New York: McGraw-Hill; pp. 1947-1966.

26. Swynghedauw B. (1986) Developmental and functional adaptation of contractile proteins in cardiac and skeletal muscles. Physiol. Rev. 66: 710-771.

27. Nadal-Ginard B, Mahdavi V. (1989) Molecular basis of cardiac performance. Plasticity of the myocardium generated through protein isoform switches. J. Clin. Invest. 4: 1693-1700.

28. Schwartz K, Chassagne C, Boheler KR. (1993) The molecular biology of heart failure. J. Am. Coll. Cardiol. 22: 30A-33A.

29. Colucci WS. (1997) Molecular and cellular mechanisms of myocardial failure. Am. J. Cardiol. 80: 15L-25L.

30. Bristow MR, Anderson FL, Port JD, et al. (1991) Differences in $\beta$-adrenergic neuroeffector mechanisms in ischemic versus idiopathic dilated cardiomyopathy. Circulation 84: 1024-1039.

31. Rahko PS. (1994) Comparative efficacy of three indexes of left ventricular performance derived from pressure-volume loops in heart failure induced by tachypacing. J. Am. Coll. Cardiol. 23: 209-218.

32. Cohn JN, Ferrari R, Sharpe N, on behalf of the International Forum on Cardiac Remodeling. (2000) Cardiac remodelingconcepts and clinical implications: A consensus paper from an international forum on cardiac remodeling. J. Am. Coll. Cardiol. 35: 569-582.

33. Weiss A, Leinwand LA. (1996) The mammalian myosin heavy chain gene family. Ann. Rev. Cell. Dev. Biol. 12: 417-439.

34. Miyata S, Minobe WA, Bristow MR, Leinwand LA. (2000) Myosin heavy chain isoform expression in the failing and non-failing human heart. Circ. Res. 86: 386-390.

35. Vanburen P, Harris DE, Alpert NR, Warshaw DM. (1995) Cardiac VI and V3 myosins differ in their hydrolytic and mechanical activities in vitro. Circ. Res. 77: 439-444.

36. Imamura SI, Matsuoka R, Hiratsuka E, et al. (1991) Adaptational changes of MyHC gene expression and isoenzyme transition in cardiac overloading. Am. J. Physiol. 260: H73-H79. 
37. Herron TJ, McDonald KS. (2002) Small amounts of $\alpha$-myosin heavy chain isoform expression significantly increase power output of rat cardiac myocyte fragments. Circ. Res. 90: 1-4.

38. Litten RZ 3rd, Martin BJ, Low RB, Alpert NR. (1982) Altered myosin isozyme patterns from pressure-overloaded and thyrotoxic hypertrophied rabbit hearts. Circ. Res. 50: 856-864.

39. Reiser PJ, Portman MA, Ning XH, Schomisch Moravee C. (2001) Human cardiac myosin heavy chain isoforms in fetal and failing adult atria and ventricles. Am. J. Physiol. 280: H1814-H1820.
40. Razumova MV, de Tombe PP, Moss RL. (2001) Simulations predict that expression of small amounts of $\alpha$ MHC in mammalian ventricle significantly accelerates the rate of rise of force. Biophys. J. 80: 261 a.

41. Jones WK, Grupp IL, Doetschman T, et al. (1996) Ablation of the murine alpha myosin heavy chain gene leads to dosage effects and functional deficits in the heart. J. Clin. Invest. 98: 1906-1917.

42. Morkin E. (2000) Control of myosin heavy chain gene expression. Microsc. Res. Tech. 50: 522-531. 